\title{
Tattooed Vikings, Racial Politics, and the Imaginary Middle Ages
}

Vikingos tatuados, política racial y la Edad Media imaginaria

\author{
Arwen A. Taylor \\ Arkansas Tech University \\ ataylor52@atu.edu
}

\begin{abstract}
Resumen
Este artículo toma la representación del tatuaje en la serie de televisión Vikings, como medio para abordar las ramificaciones políticas de un medievalismo popular. En el ensayo se considera la importancia que tienen los tatuajes aplicados a varios personajes del programa (en especial los de Rollo, Floki y Ragnar). Todos los personajes se basan sin mucha rigidez en figuras de la historia y leyendas escandinavas. El objetivo es examinar la manera en que los cuerpos masculinos, tatuados e idealizados del programa de televisión se entrelazan con los deseos modernos de historia y encarnación, un vínculo de deseo que resulta especial y alarmantemente evidente en el reciente resurgimiento del etnonacionalismo de extrema derecha en Estados Unidos y Europa.
\end{abstract}

Palabras clave: Serie televisiva Vikingos, medievalismo, tatuajes, etnonacionalismo blanco, masculinidad

\begin{abstract}
This paper takes the representation of tattooing on the television series Vikings as a site through which to address the political ramifications of a popular medievalism. The essay considers the significance of the tattoos applied to several characters in the show (Rollo, Floki, and Ragnar in particular), all of whom are loosely based on documented figures from Norse history and legend. The paper explores how the idealized, tattooed male bodies of the television show intersect with modern desires for history and embodiment, a nexus of desire that is particularly and troublingly evident in the recent resurgence of far-right ethnonationalism in the United States and Europe.
\end{abstract}

Keywords: Vikings television show, medievalism, tattoos, white ethnonationalism, masculinity

Fecha de recepción: 26 de noviembre de 2018 | Fecha de aceptación: 19 de febrero de 2019 


\section{Introduction}

lthough there is little evidence that the Viking culture of early medieval
northern Europe practiced tattooing, the television series Vikings, which
has aired on the History Channel since 2013, has gradually adopted a wide-ranging aesthetic of intricately tattooed bodies in connection with its imagination of Viking culture. The show is initially set just before the Viking Age began in earnest with the sack of Lindesfarne in 793, while its characters are still relatively isolated in their fictional Norwegian village of Kattegat. Tattoos begin to appear about halfway through the first season, suggesting the changing relationship of these characters to their own communities, the world beyond, and the boundaries of their culture, largely in terms of masculine prowess and martial achievement. This tattooing is thus legible not only as a way of figuring identity and culture within the show, but also as a signifier that speaks to a wider discourse in which the Middle Ages is often regarded simultaneously as a site of origins and alterity, a period of fascinating difference where we nonetheless look to find the pareddown roots of our own culture.

As a modern text that self-consciously aims to (in some degree) represent the Middle Ages, Vikings is an entry in the phenomenon of "medievalism," which Elizabeth Emory and Richard Utz define broadly as "the ongoing process of recreating, reinventing, and reenacting medieval culture in postmedieval times" (2). Emory and Utz further point out, however, that "medieval culture" does not have any single unified referent in history or geography. They follow Leslie Workman in emphasizing the inevitable "presentism" in medievalisms: "the fact that an individual's interpretation of the Middle Ages always reveals at least as much about that person's present concerns as about whatever the Middle Ages may actually have been" (4). Vikings' use of tattoos, especially in terms of the masculine body, is very much in keeping with this latter point about medievalism. The tattooed Vikings of the television show suggest a great deal more about modern investments in and desires for history, and its echoes in the present, than they do about real historical Norse culture. In the choice to represent Viking characters as elaborately tattooed, the non-medieval bodies of the actors are made to figure the limited 
Tattooed Vikings, Racial Politics, and the Imaginary Middle Ages

sense of historical alterity the show hopes to create. They embody an expression of identity in terms of gender and culture that remains legible to modern viewers, though within a textual vehicle that fantasizes those things as a feature of the past.

The topic of medievalism has gained a new political urgency in recent years with the surge of far-right ethnonational movements in Europe and the United States, many of which are fascinated by the medieval past. Medieval history and culture have been appropriated by such nationalists, who mistake the Middle Ages for a period of white European racial purity, for centuries; the pre-Christian Germanic cultures in particular are often plundered by white supremacists in search of a historical basis for their specious claims to racial essentialism and primacy. Thus, for example, participants in the 2017 "Unite the Right" rally held by white ethnonationalists in Charlottesville, Virginia (United States) carried shields and banners marked with Norse symbols, Celtic crosses, and the Deus vult crusading motto (see Livingstone; Ulaby; Little, for journalistic responses to the medieval appropriations visible in Charlottesville). ${ }^{1}$ At this and other moments in the history of white supremacist agitation, masculine bodies tattooed with Norse runes or carrying shields and banners marked with Norse iconography have been a visible mainstay, making for a disquieting coincidence with the prominence of tattooed Norse male bodies on Vikings. Without attributing any ill motives or ethnonationalist sympathies to the show or its creators, it is nonetheless essential to consider how discourses within and without the television show intersect, how the narrative of Norse medievalism available on television and the emboldened fringe political movement for white supremacy both connect to the larger cultural imagination of Vikings and history. Therefore, this essay represents an attempt to explore that connection, by examining first the use of tattoos within the television show, and then the ways in which those idealized, tattooed bodies might carry

\footnotetext{
${ }^{1}$ Academic societies dedicated to medieval studies responded to the events of Charlottesville with a statement "condemn[ing] the appropriation of any item or idea or material in the service of white supremacy", and asserting that "the medieval Christian culture of Europe is indeed a worthy object of study," and that responsible attention to it will find "a medieval world that was as varied as the modern one," but emphatically not "the origin of a pure and supreme white race." The full statement is available at, among other places, the Issm website ("Medievalists Respond to Charlottesville").
} 
inadvertent political weight in the broader culture. The paper suggests that, through its claims to historicity, the television show may be unwittingly contributing to the misappropriation of the medieval past in order to shore up modern myths about the history of race.

\section{Tattoos and Masculinity}

The tattooing shown on Vikings balances an interest in creating a sense of historical alterity with the necessity of representing characters in terms that will be legible to viewers. These tattoos work, in part, to depict a culture's difference and distance, incorporating elements that cannot be completely apprehended by the viewer; in some cases, particularly that of the show's protagonist Ragnar, the tattoos are indeed so divergent from the aesthetics of modern tattoos that they are difficult to completely decipher. This does not mean, of course, that those tattoos are more historically authentic, but merely that they contribute to the show's "worldbuilding" in a way that emphasizes that world's strangeness. However, despite a few specific sites where they are meant to be difficult and alien, the tattoos of Vikings are in general easily legible in a scheme of masculine performance and identity, reflecting the use of tattoos through much of 2 oth century western culture to evoke belligerent masculinity and/or social deviance. ${ }^{2}$ The difference is that as masculine belligerence is at the center of the Viking culture on display, tattooing does not mark a deviant masculine identity, but rather a focal, institutional mas-

\footnotetext{
${ }^{2}$ While tattoos in most western cultures are not mainstreamed at sites of overt institutional power (e.g., finance or government), it is true they have eroded as markers of deviance as they have become increasingly available as objects of consumer culture. Oksanen and Turtiainen find, for example, that "The sociology of the body has recently started to approach tattooing as a form of self-expression and body politics, hence opening the way to a positive diagnosis of tattooing" (112). They cite Susan Philips to note that the degree of deviance tattoos are taken to signify will likely accord with the class perception of the tattooed subject. "While middle-class tattooing seems to be a partly safe way of expressing the self, a lower-class status can change how other people read the signs of the body; the self-expressive status of tattooing as art can turn out to be the mark of criminality" (116).
} 
culine prowess. By projecting this established, known, and therefore ideologically unthreatening tattooing culture onto the Vikings, the show is able to indulge in the tattoos' romanticization of the hypermasculine body without having to negotiate the possibility of genuine subversion or resistance. That is, these tattoos allow the viewer to enjoy a carnivalesque fantasy of resistance, safely enclosed in a visual text where the tattooing - and the violent masculinity-are entirely mainstream. Tattoos mark these versions of the Vikings as only partially other, partially strange, participants in a culture that is construed around an exhibition of masculinity that can therefore be fetishized at a safe distance.

For the most part, tattoos are built into this world without explicit comment. Characters do not make overt reference to their tattoos, nor to the technology used to create them. Viewers are thus left to work out for themselves what the tattoos might signify. The closest that the show comes to articulating a theory of its widespread tattooing comes with the only scene in which we see, fleetingly, a new tattoo being created, in a context that suggests it marks a passage from childhood into adulthood. Bjorn, the son of the show's protagonist Ragnar Lothbrok, is an adolescent with no tattoos for the first two seasons; he emerges at the start of season 3 with a tattoo on the back of his neck. In season 4, Bjorn takes a survivalist journey into the interior Norwegian mountains, in the course of which he will prove himself by fighting and killing a bear in single combat (4.03, "Mercy). The struggle with the bear can be understood to signify something beyond just one more violent masculine exploit. With this, Bjorn demonstrates his capacity to endure, on his own, the unpredictable dangers of the wildest recesses of the world beyond Kattegat, and might even be said to have symbolically confronted and controlled the untamed parts of his own self (the name Bjorn means bear in Old Norse as well as in most modern Scandinavian languages). Immediately after this scene, we see Bjorn in his cabin, chest and back tattoos exposed, applying a new tattoo to his forearm. This is the only moment at which the show has depicted the creation or application of a tattoo, and it seems clear that it is meant to memorialize this coming-of-age, Bjorn's achievement as a self-reliant, hypermasculine adult Viking warrior.

Tattoos as a feature of the show's background and worldbuilding generally reflect this ethos. Masculine bodies that are remarkable for their strength and 
martial prowess - for their performance of Vikingness - are marked with tattoos, especially on the chest, arms and back, drawing visual attention to the built-up muscles below the skin. In particular, the character of Rollo (based loosely on the historical Viking leader, and later Norman duke, Rollo, or Göngu-Hrólfr) embodies this Norse masculine ethos, tied equally to his gender performance and his Viking identity. The first glimpse of Rollo's tattoos comes when his body is exposed for baptism as a part of an agreement with the Christian king Aella of Northumbria (1.07, "A King's Ransom"). The tattoos shown here constitute a coherent scene depicting, across Rollo's arms and chest, the mythological narrative of two wolves, Hatí and Sköll, who chase the sun and the moon across the sky. ${ }^{3}$ This depiction represents a connection to, and investment in, an element of the metaphysical narratives of Rollo's own culture, put on display at precisely the narrative point of encounter with a different culture, with its rituals and metaphysics. The mythological images chosen for Rollo evoke the untamed predatory aggression of the natural world and connect his body to the mythological, apocalyptic violence promised by the supernatural. Furthermore, these tattoos appear on a masculine body that has been shaped and polished to meet the highest standards of modern sexual aesthetics, with its rippling pectoral muscles under mostly hairless skin. The exposure of his skin at this moment of confrontation with another culture and belief system suggests a certain vulnerability-as an outsider who does not know the language or really comprehends the ritual he is at the center of, he is at risk not just physically, but ideologically. At the same moment that the exposure of his body to the Christian enemy invites an incursion into his Viking identity, the indelibility of his Viking tattoos over-assert that Norse identity against this threat; neither his tattoos, nor his Vikingness, can be washed away in Christian baptism.

\footnotetext{
${ }^{3}$ The meaning of the tattoos is explained in a brief behind-the-scenes video created by the History Channel, in which it is explained that "Rollo" means "famous wolf" and so the mythological scene has particular significance for this character. The discussion of Rollo's tattoos defaults repeatedly to a discussion of the actor's muscular upper body and the frequency with which the character is shown shirtless, underscoring the intersection of masculine identity and display with tattooing in the meta-discourse of the show. (Hrolvr is a contracted form of Hrod-ulf, which indeed means "fame-wolf.") ("Vikings: Rollo's Tattoos.")
} 
Rollo is portrayed as a berserker, a type of Viking warrior said to have gone into battle naked (though whether this would have been the case historically remains disputed); thus Rollo's tattoos are most often visible in the heightened masculine performance of shirtless warfare. ${ }^{4}$ Again, the fact of this shirtlessness codes his body as desirably masculine in especially modern terms, and here, the exposure of skin both evokes and denies the vulnerability of the hypermasculine body. The exposed skin that would put a lesser Viking in danger claims instead the invulnerability of Rollo's body, with or without armor. Again, his tattoos project his Viking identity over and against the identity of his enemies, at precisely the site where he is the most potentially vulnerable-the skin - as a refutation of vulnerability. Somewhat ironically, Rollo does eventually abandon his Norse compatriots to take up a role in the Frankish court, and after this, his tattoos are no longer displayed in public; instead, he comes to battle in full armor. Glimpses of the tattoos are now confined to bedrooms scenes, where his residual Viking identity remains fraught in the face of his Frankish Christian wife's very different ideas about sexual morality. The permanency of his tattoos, recalled in these moments, suggests the permanency of some core self that will, never be fully converted away from his Norse origins, especially in privacy and intimacy. However, they make this claim in tension with the shifting, unstable performance of his body in the world, which has otherwise adopted and continues to perform its non-Norse identity. Even in their permanency on the body, tattoos turn out to be as unreliable as any other signifier, more stable in their form than in their connection to the shifting, unstable self that lies beyond them.

Tattoos on other male bodies tend to track this same negotiation and performance of Viking identity, violent masculinity in tension with exposed vulnerability. Other berserkers also bear knotwork tattoos, visible in training or in battle sequences, including the sometime villain Jarl Borg. In the course of the show,

${ }^{4}$ The berserker warriors are reported by Snorri Sturluson, in Ynglingasaga, to have fought "without armor and acted like mad dogs or wolves." It remains disputed whether this represents a correct understanding of the etymology of the word (i.e., "bear [of] shirt") or the word should instead be interpreted as "bear-shirt," associating the berserkers with a Norse bear cult (Liberman, 402-3). 
Borg's tattoos are made visible twice in the course of the show: First in a battle scene where he, like Rollo, fights shirtless (2.01, "Brother's War"), and then again when, after a series of betrayals, he is finally tortured and executed by Ragnar and his allies. As Borg submits silently to the blood eagle ritual, the exposure of his tattoos underscores his conformity to the cultural demands on the masculine body; here is not invulnerable, but he receives his death in a display of stoic, unflinching Viking demeanor (2.07, "Blood Eagle").

In part, the hypermasculine body aesthetics of Vikings may be a response to a wider crisis in masculinity. The proliferation of action heroes that look like-and are played by-bodybuilders in the 1980 os and since has been interpreted as responding to such a crisis, asserting hypermasculine bodily aesthetics against anxieties about the role and performance of modern masculinity (see for example Tasker, 109-111). Whether or not the representation in Vikings is broadly symptomatic of similar cultural troubles, the show is certainly legible in terms of viewers' relationship to a troubled masculine identity. A number of scholars have suggested a link between the mostly-male white nationalist movement and resentment over the shifting stakes and expectations for modern masculine performance. ${ }^{5}$ However, the relationship between the masculine embodiments of these imagined Vikings and their tribal (proto-national) identity seems clear. Their sinewy, semi-nude, and tattooed bodies are displayed most often in terms of their utility for tribal violence-that is, violence that pits one's own kind or people against an outsider group. Such violent masculine aesthetics are set invariably against an Other marked not only by linguistic, cultural, and theological difference, but also by their less exaggerated masculinity: the large but softer body of King Aelle; King Ecbert of Wessex, introduced soaking in his Roman bath and

\footnotetext{
${ }^{5}$ Sociologist Michael Kimmel summarizes the dynamic as one that preys on downwardly-mobile men in particular, in an interview with Mother Jones: "Joining up is a way to get it back, to restore your masculinity. The white nationalist organizations are fairly explicit in this: 'Join us and you feel like a real man. Join your brothers, your comrades' ... You feel isolated and alone and despairing. You feel like you're failing your family. Then these guys come along and say, 'No, you're great, you're awesome. You're one of us. We are your brothers.' You get community, camaraderie; you get people who are validating your masculinity. Then, of course, the sacred mission of preserving the white race" (Gilson).
} 
Tattooed Vikings, Racial Politics, and the Imaginary Middle Ages

complaining about soldiers walking through with muddy boots (2.02, "Invasion); the Frankish court with its high towers, luxurious fabrics, and soldiers that fight in obedient formations rather than berserker rages. Tattoos that appear only on Viking bodies, and primarily on male ones, ${ }^{6}$ mark an intersection of masculine discipline and display with proto-nationalist violence. For viewers as concerned with their own masculinity as they are with the character of their nation, such images may read as an appealing projection of their own most out- of-reach, idealized self, as they wish they could exist in their community, nation, and world.

\section{Tattoos and Authority}

While Rollo and Bjorn embody a belligerent masculinity cultivated for its capacity for violence, the show's protagonist Ragnar Lothbrok represents a more cryptic and cerebral way of being, occupied with control and authority, rather than only violence. This is a character he is allowed to cultivate (in their society and on the show) only because he is an exceptional warrior as well, perfectly capable of violence when it suits his purposes. Ragnar's tattoos, gradually expanding across his skull rather than his torso, reflect his tendency for secrecy and scheming; he defeats enemies and gains power as much by out-maneuvering them politically as by cutting them down in battle. These tattoos are stranger and more difficult to interpret than most of the other tattoos on Vikings, in terms of both their placement

\footnotetext{
${ }^{6}$ There are a few female characters on Vikings who have tattoos as well. The princess Aslaug, Ragnar's second wife, has a small tattoo below her wrist; Ragnar's first wife Lagartha eventually acquires a chevron pattern on her left shoulder and upper arm. Both of these are relatively unobtrusive tattoos, as legible according to modern expectations for feminine (delicately lined, covered by clothing) tattooing as the berserker tattoos are masculine; neither is visible as regularly as Ragnar's, Rollo's, or Bjorn's. Astrid, a shieldmaiden who first appears in the fourth season, does have a prominent knotwork tattoo on her chest and neck, reminiscent of the berserkers' chest tattoos. However, Astrid's interests in martial arts and her sexual relationship with Lagertha can be taken to indicate that she does not fall fully, in her gender performance, on one side of a neat gender binary.
} 
and their figuration, though they nonetheless expand around his head alongside the expansion of Ragnar's political capital and power in the world.

Ragnar (based on a more-or-less historical figure from the sagas who is associated with the extensive raiding of the English and Frankish coasts in the 9th century) appears initially in the show un-tattooed, and not yet distinguished by any achievement greater than curiosity and an ambition to explore to the west of Scandinavia. Despite discouragement from the local Earl Haraldson, Ragnar and his friend Floki use their newly invented Viking long-ship to travel across the North Sea and sack Lindesfarne Monastery on the north-east coast of England, the event generally understood to have launched the Viking Age in Europe. Tensions escalate after their return, until Ragnar challenges the earl to a duel in single combat; defeating Haraldson earns him the earldom of Kattegat and begins his ascension up the disordered hierarchy of Viking political society. Ragnar's first tattoo appears in the aftermath of this duel. During the duel, Ragnar's head is clearly un-tattooed, though the undercut below his braid has been freshly shaved, as if in preparation. In the scene immediately following, as Ragnar comes into the hall to take his place as the new earl, the camera moves in for a few close-ups of the image now inked onto the right side of his head: an abstract, stylized raven, presumably selected to reflect his identification with the Norse god Odin and his two ravens. The raven tattoo memorializes not just a significant victory at arms, but a shift in Ragnar's role in Kattegat and Kattegat's entry into the world beyond, as the Norse have begun to expand their interests beyond their local territory. The skin that Ragnar shaves and tattoos evokes not just vulnerability, but a point of contact and a boundary between the self and the space surrounding. Ragnar's movement through both the cultural and political space of Kattegat, and the movement of Vikings through the space of Europe, is in the midst of being re-negotiated as Ragnar chooses to inscribe that boundary with a religious symbol that evokes Odin's own negotiation of natural and supernatural, the world and his oversight of it. ${ }^{7}$

\footnotetext{
${ }^{7}$ In the Gylfaginning, the two ravens Huginn and Muninn (thought and memory) fly around the world each day, bringing back tidings to tell Odin as they perch on his shoulders. This background suggests a further valence to Ragnar's choice of tattoo, e.g., that Ragnar is memorializing his ascent to the rulership using a symbol that suggests power managed by way of information.
} 
Tattooed Vikings, Racial Politics, and the Imaginary Middle Ages

Ragnar continues to add tattoos to his increasingly shaved head as his political authority expands. In season 2 we eventually see that Ragnar has added non-figural, decorative tattoos around the original image; later that season, after Ragnar has outwitted and executed the treacherous Jarl Borg, he is shown immediately afterwards with similar small knotwork tattoos on the other side of his head. In the season 2 finale, Ragnar kills the king of Denmark and effectively takes his place; the final imagery of the season has him perched moodily atop a wintery cliff, tattoos now wrapping all the way around the back of his head and expanding down his neck (2.10, “The Lord's Prayer"). In season 3, when Ragnar's close friend, the Northumbrian sometimes-monk Athelstan is murdered by Floki (3.6, "Born Again"), Ragnar shaves the last of his crew-cut in an act of enraged mourning, opening up new cranial space for further tattooing. In the next episode, he arrives in Paris with his tattoos extending higher than ever before toward the crown of his skull, ready to besiege the Franks (3.7, "Paris"). The tattoos on Ragnar's head expand in pace with the turns of his life, moments of triumph and change, and re-orderings of his self as a Viking and a leader to various others both inside and outside of Viking culture.

As his tattoos expand, the original figural image, the bird, becomes less and less visible in the pattern of lines and knots around it, disguising what was a representation of something identifiable with images that cannot be separated, parsed, or interpreted. Just as Rollo had tattoos instead of armor, Ragnar has tattoos instead of hair; that is, his tattoos are in many shots indistinguishable from other physical details of his body. The tattoos reflect his steadily expanding sphere of influence and the reach of his leadership, distinct from the tattoos anyone else on this show has, or the kinds of tattoos that carry obvious meaning for modern viewers. While the berserker tattoos are legible in fairly straightforward ways, drawing attention to the pectoral and arm muscles of the Vikings who wear them, Ragnar's tattoos are largely opaque-perhaps gesturing cyclically toward the very problems with interpretation that they pose. In their figural ambiguity, they evoke Ragnar's clever but enigmatic ability to re-make the world as he wants it-just as he remade, literally, the physical space of his skull, replacing natural hair with curling lines of ink that, in many shots, can be mistaken for hair. What seems natural and inevitable blends with what is artful and manipulated as Ragnar, scheming relentlessly 
under his crown of tattoos, plots and long-cons his enemies toward an endgame that only he has the capacity to see at a distance. The viewer learns not to get too comfortable with their ability to interpret either the signs of Ragnar's body or the intent of his authority.

Ragnar's tattoos peak as his character reaches a height of power and influence; his fortunes and his tattooing culminate with the raid on Paris, and as he slips into an erratic decline ending with his death (as per Völsunga saga)in a Northumbrian snake pit, his tattoos stop growing and begin to fade. Ragnar, his tattoos, and his fate are all equally inscrutable, and in their genuine strangeness difficult to easily appropriate for any one ideological application. In this way, they contrast instructively with the character Floki's tattoos, which appear first after a seven-year jump midway through season 4, also inscribed across a shaved head. Floki's tattoos express a highly legible Viking identity on a character who is particularly committed to his Norseness and anxious about outside influences. Floki is the show's most devout believer in the Norse pantheon, reflexively suspicious of other believers, Christians in particular. His murder of Athelstan is motivated by Athelstan's re-commitment to his on-again/off-again Christianity, entailing as it does a rejection of Floki's gods. As a violent enthusiast for maintaining the ideological boundaries of his culture, Floki's character makes for an unsettling parallel with modern interests that take Norse history as evidence of the need for ethnically defined national boundaries, regularly exploiting to the same set of symbols that figure in Floki's tattoos, the runes that made up the Futhark, the pre-Christian Germanic alphabet. Floki's tattoos are two lines of runes that arc across his head and down the back of his neck, making references to Loki and to giants or trolls. ${ }^{8}$ These are mythologically forceful tattoos that express a core Viking identity in a mode instantly legible to the modern viewer. The tattoos are available, even demanding, to be decoded, and evoking connections between Floki's cultural tribalism, his genius (like Ragnar's, they draw attention to his head rather than to his body), and

\footnotetext{
${ }^{8}$ The runes on the right side of Floki's head are transcribed and translated as pursamegin, a compound that would mean "giant-power" or "troll-force" in Old Norse, in the blog Renorseful, written by a researcher in medieval Scandinavian languages (Maja). The tattoo on the other side appears to begin with the word Luki, in the Younger Futhark.
} 
Tattooed Vikings, Racial Politics, and the Imaginary Middle Ages

his legendary-historical significance as the creator of the Viking longship and the discoverer of Iceland. ${ }^{9}$ Stamping this character, who is both dogmatically Norse and central to (this version of) Viking history, with runic tattoos makes for a troubling parallel with modern white supremacy that draws on the same Germanic runic symbols and faux-history, to a xenophobic end to which Floki might not be unsympathetic.

\section{Fantasies of History, Fantasies of Race, and Tattooed Bodies}

As I wrap up revisions of this essay, the news website Reuters has just published a series of photographs documenting a National Socialist Movement rally held just over an hour from where I teach, in Ward, Arkansas ("White nationalist rally"). Participants in the rally can be seen carrying banners and shields, like modern militants headed to a neo-medieval battlefield, emblazoned with an odal-rune $(\widehat{\lambda})$ against a deconstructed American flag. Instead of a cross, they burned an odalrune. Etymologically, this grapheme from the Elder Futhark means "heritage" or the right to land. One of the participants shows off a runic tattoo that spells outSTR M XXT H presumably meant to read STRENGTH. Another wears a hat sporting the double sig-rune ( $\mathrm{H}$ ), notoriously used by the paramilitary Schutzstaffel (ss) branch of the Third Reich, and by white supremacists and neo-Nazis since.

White supremacist enthusiasm for medieval, and particularly Viking, history is well established; white supremacist symbolism often incorporates swords and shields, and white nationalists speak lovingly of a fictitious medieval past, in which all of Europe was occupied by a homogeneous, pure white race. ${ }^{10}$ Viking landings

${ }^{9}$ According to Landnámabók, Hrafna-Flóki (followed) set out to find the land described by Garðar Svavarsson, was led to Iceland by a raven, and landed at Vatnsfjord. However, the first Norse settler was Ingólfur Arnarson, who built a homestead in Reykjavík by 874. Vikings may be collapsing these two figures.

${ }^{10}$ This view is factually inaccurate, given the diversity of Europe in the Middle Ages; the scholar Paul B. Sturtevant has devoted a long series at his blog, The Public Medievalist, to disabusing readers outside of medieval scholarship of their vision of an all-white medieval Europe (Sturtevant, 
in North America are taken as evidence of "a [white, northern European] historical claim over North America, stretching especially from the Northeast coast to the Pacific Northwest" and white supremacists "use the myth of Vinland to position themselves as righteous defenders in the wars of race and religion they believe are coming" (Perry). Such beliefs were on display when a white supremacist, who had posted "Hail Vinland!!! Hail Victory!!!" days before on his Facebook page, shouted ethnic and religious slurs at women in hijab on a train in Portland, Oregon, and then fatally stabbed two people who intervened (Holpuch). Meanwhile, the Southern Poverty Law Center reports of a neo-Odinist religion, the Holy Nation of Odin, which is run by an incarcerated, avowed white supremacist responsible for a group called the Vinland Folk Resistance. The organization funds itself in part by selling re-creations of Vikings swords, clothing, and drinking horns (Keller).

The appropriation of runes by such groups was made widespread by the Nazis; in addition to the ss double-sig symbol, specific ss branches used odal $(\widehat{\lambda})$, hagal $(*)$, and $\operatorname{tyr}(\uparrow)$ runes as insignia. European and American white nationalism continues appealing to Old Norse history as a way of justifying their claim of entitlement to a racially homogenous present, so that Norse runes are regularly used as a part of white nationalist symbolism and iconography. The 1980 s white supremacist band Screwdriver, the 1990s racial-separatist group Volksfront, and the National Alliance in the United States have all used the algiz or elhaz $(\Psi)$ rune in their insignia (Hate On Display). The Anti-Defamation League and the Southern Poverty Law Center have gathered images of tattoos that combine the elhaz rune with the numbers 14 and 88 (both of which bear coded meaning for white supremacy), as well as the phrase "white power." While tattooing is-of course-not an inherently or diagnostically white nationalist practice, and enthusiasts of medieval

"Race"). But it is also anachronistic, in that racial categories and ideologies in the Middle Ages simply do not align with modern notions of racial categories. Geraldine Heng emphasizes that race "has no singular or stable referent: that race is a structural relationship for the articulation and management of human differences, rather than a substantive content" (262), and points out, of the racializing of religious difference in the Middle Ages, that "religion - the paramount source of authority in the Middle Ages - can function both socioculturally and biopolitically" so that "peoples of a detested faith" can be essentialized as a racial other (268). 
Tattooed Vikings, Racial Politics, and the Imaginary Middle Ages

history or Scandinavian culture make use of runes and other Norse iconography for perfectly benign reasons, catching sign of a runic or otherwise evidently Viking tattoo (e.g., an image of Thor's hammer, a Vinland flag, or a so-called "Viking compass") creates what Paul B. Sturtevant calls a "Schrödinger's medievalism": "if you spot someone wearing one, it is not immediately obvious whether the person sporting it is doing so for toxic reasons. And naturally, not knowing this can be anxiety-inducing." The way that the Vikings are described and represented in popular culture thus comes with a racial and political weight worth evaluating. This is particularly true given the widely reported spike in white nationalist hate crime in the United States since the 2016 presidential election of Donald Trump, which the creators of Vikings could not have predicted when the show premiered in 2013.

The use of tattooing on Vikings is emblematic of the fraughtness of historicity as a specter of medievalism, and of the ethical quandaries evoked as elements of history are raised and put to the service of modern political agenda. These tattoos are not strictly historical. The only suggestion that the historical Vikings practiced tattooing comes from the account of Ahmad ibn Fadlan, who in 921 was sent on a journey north from the court of the Caliph Muqtadir, and encountered on the way a group of travelers he calls the "Rūsiyyah," who are frequently identified as a group of Swedish Vikings. ${ }^{11}$ In his account of this group, Ibn Fadlan includes the detail that "Each man, from the tip of his toes to his neck, is covered in dark-green lines, pictures and such like" (Montgomery 6). ${ }^{12}$ Whether this describes a tattooing

\footnotetext{
${ }^{11}$ It is also not entirely established who Ibn Fadlan means by the "Rus", exactly: there is still some debate over whether this is a Norse or a Slavic group, or an ethnic term at all. James E. Montgomery explains some of the difficulties: "The Arabic sources in general quite simply do not afford us enough clarity. The tendency among scholars is to presume that different Arab authors mean the same thing when they apply the names Rūs or Majūs to the people they describe. After a perusal of the sources, this strikes me as a perilous presumption. It is a distinct possibility that the medieval Arabs themselves were perplexed as to the exact identity of the Rūs, confusing, say, two different peoples." Montgomery further quotes the early Slavic archaeologist Pavel Dolukhanov: "Arab writers who often used the word 'ar-rus' never attached to it any ethnic significance. They viewed the 'ar-rus' as warriors and merchants regardless of their ethnic affiliation. The same applies to Byzantine sources, which were often mentioned as 'people calling themselves the Ross' (Rhos), and who in reality were groups of Scandinavians accomplishing various missions" (Montgomery 3-4).

12 The same line is translated by Lunde and Stone: "From the tips of his toes to his neck, each man is tattooed in dark green with designs, and so forth" (Ibn Fadlan 46).
} 
practice, and whether it is indeed a group of Norse traders, are open questions; nonetheless, this is almost certainly the basis for Vikings' choice to incorporate tattoos into its representation of the Viking world (Staggs).

This does not mean, of course, that there is anything objectionable to making the Vikings on the television show tattooed. Medievalism is always a process of invention, re-mixing, borrowing, and fictionalizing, with much more regard for modern fantasies about history than history itself. The creators of the show have almost certainly based their choice to tattoo the Vikings on Ibn Fadlan, but the extent, style, and semiotics of those tattoos is the result of an expressly modern series of creative decisions. ${ }^{13}$ However, in a political climate where medieval history is often appropriated and deployed as justification for white nationalist and xenophobic rhetorical ends, these decisions have ethical consequences that exceed the intention behind them. The metadiscourse of Vikings suggests a strategy of selling itself in terms of historical authenticity. For one thing, airing the show on History (rather than, say, Syfy, which would mark it as speculative fiction; or нво, which would convey prestige drama) suggests a primacy of "historical" over "fiction" in its genre; that is, it is framed as an adaptation of real history, rather than a fiction loosely inspired by an array of history and legend. In fact, the History network airs a documentary show Real Vikings alongside Vikings, which "dives deep into the history and archaeology that inspires the popular drama Vikings" and promises a "never-before-seen view of what Vikings were really like" ("Real Vikings"). Furthermore, as Michael Hirst, the show's creator who also writes every episode, discusses the show in interviews, he invariably underscores its "authenticity," the "reality" of its presentation of history. In one interview, Hirst obliquely discusses the balance of history and fiction in his creation:

${ }^{13}$ Justin Pollard, interviewed in the article cited, mentions Ibn Fadlan as a source that describes Viking funeral practices, and indeed, the funeral depicted in the first season of Vikings closely follows the practices given in ibn Fadlan. Descriptions of Viking culture written for a general audience often draw, implicitly or explicitly, on Ibn Fadlan. Whether or not Michael Hirst has personally studied Ibn Fadlan's Risala, it is almost certainly the source for many of the details he understands to be historically "accurate" on the show. 
Tattooed Vikings, Racial Politics, and the Imaginary Middle Ages

... as a writer you need to ask yourself whether it seems truthful. I'm not writing fantasy -this isn't Game of Thrones; I don't have dragons. I can't just make it up- it has to seem real. One of things I'm proudest of is that most of what we do is for real - our guys actually fight, row and ride horses. In the last season they had to hoist two-tonne boats up cliff faces, and they really did it. I think the reality of it shows. ("Vikings: An Interview")

Hirst emphasizes that he can't just "make up" history, because it has to seem real; that is, the story he makes up has to be framed in a way that makes it seem accurate. Implicit here is the problem that audiences are not really qualified to judge whether the costumes, characters, events, language, or material culture of a representation are "accurate"; they only know what strikes them as accurate, mostly based on their previous encounters with other medievalisms representing the same period or cultures. Hirst is aware that his creation is compelling in part via its framing as history, but that it is less important that it be historically accurate (an impossible expectation for any work of fiction) than that it resonate with what audiences already believe about history as they enter this show's version of it. Instead, this speaks to the desire for an accessible history: a history that will be comprehensible, aesthetically pleasing, inviting and satisfying to the modern audience; a history we can make sense of, whose differences are exotic but not threatening-and which are available to justify and shore up our beliefs about the present. That structure-of claiming historicity while writing fiction-is the same which licenses any political exploitation of what "seems" historical to justify the ideologies of the present, including those associated with white ethnonationalism.

The white-supremacist appropriation of Old Norse iconography relies on a fantasy of northern European history, the dream of some lost period when a racially pure, correctly masculine, and rightfully aggressive white culture pillaged its way around Europe. Any real attention to what we know of history dismantles these claims almost instantly; Europe was never the racially homogenous utopia the white nationalists fantasize it to have been, nor was phenotypic race a primary organizing principle by which medieval Europeans seem to have distinguished self and other (see note 10 above). "Real" history is not the point, however. What is useful here is the history that seems - that resonates, that is familiar and desirable. Moreover, while Vikings certainly cannot be held responsible for the resurgence of 
explicit white nationalist movements in the 21st century, it is embedded in the same present and politics, the same imaginations of history and race, that have enabled this resurgence. Vikings' portrayal of romanticized, violent medieval bodies, inscribed by tattoos as exotically desirable rather than truly foreign, contributes to our perceptions of, and desires for, historical bodies. Additionally, the white body of history, as a fetishized medieval body that makes for hypermasculine achievement against a host of cultural others, has never been more available for reactionary appropriation.

\section{Arwen Taylor}

She is an Assistant Professor of English at Arkansas Tech University. Her research interests include language change and dialect, speech act theory and medieval theories of language, and, as represented here, the ethical and political dimensions of medievalism. She has published previously in the journals Arthuriana and Dictionaries.

\section{WORKS CITED}

Emery, Elizabeth, and Richard Utz. Medievalism: Key Critical Terms. Medievalism. volume V. D. S. Brewer, 2004.

Gilson, Dave. "You Can't Understand White Supremacists Without Looking at Masculinity." Mother Jones, July/August 2018. Web. https://www.motherjones. com/politics/2018/o7/men-white-racist-extremism-michael-kimmel/

Heng, Geraldine. "The Invention of Race in the European Middle Ages I: Race Studies, Modernity, and the Middle Ages." Literature Compass. 8:5 (2011): 258274.

Hirst, Michael, creator. Vikings. World 2000 Entertainment, Take 5 Productions, Shaw Media, A\&E Television Networks, and MGM Television, 2013-2018. 
Tattooed Vikings, Racial Politics, and the Imaginary Middle Ages

Holpuch, Amanda. "Man Shouting 'Anti-Muslim Slurs' Fatally Stabs Two Men in Portland.” The Guardian, 27 May 2017. Web. https://www.theguardian.com/usnews/2017/may/27/man-shouting-anti-muslim-slurs-fatally-stabs-two-men-inus

Ibn Fadlan, Ahmad. “The Book of Ahmad Ibn Fadlān 921-922." In Ibn FAdlān and the Land of Darkness: Arab Travellers in the Far North. Translated by Paul Lunde and Caroline Stone, Penguin Classics, 2012: 1-58.

Keller, Larry. "White Supremacist Running Odinist Network From MaximumSecurity Prison." Southern Poverty Law Center, 20 March 2009. Web. https:// www.splcenter.org/hatewatch/2009/03/20/white-supremacist-running-odinist-network-maximum-security-prison

Liberman, Anatoly. "Berserks in History and Legend." Russian History, 32:3/4 (2005): 401-411.

Little, Becky. "How Hate Groups are Hijacking Medieval Symbols While Ignoring the Facts Behind Them." History, 18 Dec. 2017. Web. https://www.history.com/ news/how-hate-groups-are-hijacking-medieval-symbols-while-ignoring-thefacts-behind-them

Livingstone, Joseph. "Racism, Medievalism, and the White Supremacists of Charlottesville." The New Republic, 15 August 2017. Web. https://newrepublic. com/article/144320/racism-medievalism-white-supremacists-charlottesville

Maja. "Headstrong." Renorseful, 10 May 2017. Web. https://renorseful.wordpress. com/2017/05/10/headstrong/

"Medievalists Respond to Charlottesville." International Society for the Study of Medievalism (ISSM) website, 18 August 2017. Web. https://medievalism.ne$\mathrm{t} / \mathrm{p}=79$

Montgomery, James E. "Ibn Fadlān and the Rūsiyyah." Journal of Arabic and Islamic Studies 3 (2000): 1-25.

Oksanen, Atte, and Jussi Turtiainen. "A Life Told in Ink: Tattoo Narratives and the Problem of the Self in Late Modern Society." Auto/Biography. 13: 2 (2005): 111130. 
Perry, David. "White supremacists love Vikings. But they've got history all wrong." The Washington Post, 31 May 2017. Web. https://www.washingtonpost.com/ posteverything/ wp/2017/05/31/white-supremacists-love-vikings-but-theyve-got-history-all-wrong/?utm_term=.6d8abb114be2

"Real Vikings." History. Corus Entertainment, Inc., 2018. Web. https://www.history. $\mathrm{ca} /$ real-vikings/

Staggs, Matt. "Meet the Man who Makes Sure that 'Vikings' is Historically Accurate." Unbound Worlds, Penguin Random House, 23 April 2015. Web. https://www. unboundworlds.com/2015/04/meet -the-man-who-makes-sure-vikings-is-historically-accurate/

Sturtevant, Paul B. "Schrödinger’s Medievalisms." The Public Medievalist, 28 Dec. 2017. Web. https://www.publicmedievalist.com/schrodinger/

Sturtevant, Paul B. "Race, Racism, and the Middle Ages: Tearing Down the "Whites Only" Medieval World." The Public Medievalist, 7 Feb. 2017. Web. https://www. publicmedievalist.com/race-racism-middle-ages-tearing-whites-medieval-world/

Tasker, Yvonne. Spectacular Bodies: Gender, Genre and the Action Cinema. Routledge, 2012.

Ulaby, Neda. "Scholars Say White Supremacists Chanting 'Deus Vult' Got History Wrong." National Public Radio (website), 4 September 2017. Web. https://www. npr.org/2017/09/04/ 548505783/scholars-say-white-supremacists-chantingdeus-vult-got-history-wrong

"Vikings: An Interview with the Show's Creator and Writer Michael Hirst." HistoryExtra, Immediate Media Company Limited, ввс Worldwide, 7 June 2016. Web.https://www.historyextra.com/period/viking/vikings-an-interview-withthe-shows-creator-and-writer-michael-hirst/

"Vikings: Rollo's Tattoos" (online video). History. YouTube, 4 February 2014. Web. https://www.youtube.com/watch?v=8AmXwJHLObQ

"White nationalist rally in Arkansas." Reuters, 12 Nov 2018. Web. https://www.reuters.com/news/ picture/white-nationalist-rally-in-arkansas-idUSRTS25O4R 